\title{
DIAGNÓSTICO GENÉTICO DE PRÉ- IMPLANTAÇÃO: REFLEXÃO À LUZ DA DISCRIMINAÇÃO GENÉTICA
}

\section{Daniele Fernanda Gomes Lopes}

Mestre em direito pela Unicesumar - Centro Universitário de Maringá-PR. Especialista em Direito Empresarial pela Universidade Estadual de Londrina/PR (UEL). Graduada em Direito pela Pontifícia Universidade Católica do Paraná (PUCPR), Campus Maringá/ PR. Advogada regularmente inscrita no quadro dos advogados do Brasil sob № 67.800. E-mail: <danielefernandalopes.adv@gmail.com>.

\section{Mithiele Tatiana Rodrigues}

Mestre em direito pela Unicesumar - Centro Universitário de Maringá-PR. Especialista em Direito Processual Civil, Penal e Trabalhista pela Instituição de Toledo de Ensino, Campus de Presidente Prudente de São Paulo (ITE/PP-SP - 2003), e em Direito Ambiental pelo Instituto de Direito Constitucional e Cidadania da cidade de Londrina (IDCC/Londrina - 2013). Graduada em Direito pela Faculdade de Direito de Presidente Prudente/SP - ITE - Instituição Toledo de Ensino (2002). Professora de Direito Ambiental e Constitucional na Faculdade Alvorada de Maringá/PR. Advogada em Maringá/PR. E-mail: <mithielerod@gmail.com>.

\begin{abstract}
Resumo: O avanço científico dos últimos tempos tem, cada vez mais, permitido o emprego de novas tecnologias. Mais recentemente, pretende-se fazer uso das células-tronco embrionárias para a obtenção de tratamentos a fim de recuperar órgãos de pessoas portadoras de deficiência, enfermas ou que sofreram infortúnios. No Brasil, o legislador ordinário, com a Lei de Biossegurança, permitiu a utilização de embriões in vitro para desenvolver pesquisas científicas. O Supremo Tribunal Federal admitiu a constitucionalidade dessa legislação, mais propriamente para o desenvolvimento de pesquisas com finalidade terapêutica. As pesquisas acabaram por desenvolver diversas técnicas, e uma delas é o diagnóstico genético do embrião, que pode ser pré-natal ou pré-implantacional. Esta técnica de manipulação genética, relacionada à fertilização in vitro, permite diagnosticar doenças e outras características que possibilitam aos genitores a escoIha de um entre os vários embriões a serem implantados, descartando ou congelando os demais. Através de realização de exames, como o FISH (Fluorescent "In Situ" Hibridization) para diagnóstico de patologias cromossômicas e o PCR (Polimerase Chain Reaction) para detecção de patologias gênicas, tornou-se possível selecionar geneticamente aqueles que não possuem anomalia em seu gene e descartar os demais, porque portadores de defeito genético. Essa prática de discriminação genética representa ser possível descartar aqueles embriões em que se diagnostica, por exemplo, a trissomia do cromossomo 21 , como se os portadores de Síndrome de Down não tivessem o direito de viver. Sem lei específica para proibir tal prática, a busca desenfreada da eugenia, da raça pura, do ser humano programado em laboratórios, acaba sendo a evidência desumana dos avanços da tecnologia, que necessitam, urgentemente, atuar de acordo com a igualdade, a ética e, principalmente, com o ideal para a humanidade.
\end{abstract}

Palavras-chave: Biossegurança. Embrião. Discriminação genética.

Sumário: 1 Introdução - 2 Da recente decisão do Supremo Tribunal Federal acerca do embrião humano - 3 Dos embates perante o julgado: eugenia $x$ personalidade jurídica $x$ dignidade da pessoa humana - 4 Do diagnóstico genético pré-implantacional e o dilema da eugenia à luz da discriminação genética - $\mathbf{5}$ Considerações finais - Referências 


\section{Introdução}

Com os avanços da biogenética, hoje é possível mapear o DNA de um indivíduo e descobrir se ele tem tendência a desenvolver doenças, comportamento violento, obesidade, disposição ao crime ou qualquer outro tipo de anomalia capaz de causar repúdio na vida social ou privada desse indivíduo.

Por meio das técnicas da medicina preditiva, permitiu-se ter acesso ao DNA do indivíduo. A medicina preditiva tem, como essência, a capacidade de se fazer predições sobre a possibilidade de um indivíduo adulto, embrião, feto ou recémnascido poder desenvolver algum tipo de doença em nível fenótipo ${ }^{1}$ (são as características observáveis deste ser humano, ou seja, sua aparência física, seu estado de saúde e suas emoções), tendo como base testes feitos através do DNA em nível genótipo.

Hoje, após a decisão do Supremo Tribunal Federal - STF em declarar constitucional a Lei de Biossegurança, os embriões in vitro passaram a ser utilizados para fins de pesquisas científicas, mais propriamente para o desenvolvimento de pesquisas com finalidade terapêutica. Com esta decisão, foi possível, então, a criação de novas técnicas médicas, sendo uma delas o diagnóstico genético de pré-implantação, que possibilita detectar anomalias no gene de um embrião e descartá-lo se for possuidor de uma característica defeituosa.

Dessa forma, o presente trabalho restringe-se à técnica do Diagnóstico Genético Pré-Implantacional - DGPI, que, a princípio, era utilizada em famílias em relação às quais já se conhecia uma mutação com o intuito de evitar a transmissão hereditária de anomalia genética (ligadas ao cromossomo X) ou anomalia cromossômica estrutural; contudo, após a decisão do STF, ela tem sido usada, cada vez mais, para apoio à procriação, com a finalidade de vasculhar os genes dos embriões gerados em famílias em que não há prévio conhecimento de risco genético, justamente com o intuito de avaliar a qualidade dos embriões produzidos in vitro.

Com a submissão de um embrião a exame genético de precaução em busca de anomalias, seja daquele que já se encontra no ventre materno (diagnóstico de pré-natal), seja daquele que será implantado no útero (diagnóstico pré-implantacional), se for constatado que o embrião possui uma anomalia genética, patologia cromossômica ou gênica, abre-se a possibilidade de os pais, tendo em vista o conhecimento do genoma do embrião, decidirem pela sua não implantação ou, mesmo após a nidação, de não quererem mais o seu desenvolvimento.

1 PENA, Sérgio Danilo J.; Azevêdo, Eliane S. O projeto genoma humano e a medicina preditiva: avanços técnicos e dilemas éticos. In: COSTA, Sérgio Tibiapina Ferreira; OSELVA, Gabriel; GARRAFA, Volnei (Coord.). Iniciação à Bioética. Brasília: Conselho Federal de Medicina, 1998, p. 143. 
Diante dessa problemática, desenvolver-se-ão no decorrer do trabalho os pontos controvertidos da decisão do STF que declarou constitucional a Lei de Biossegurança, esclarecendo-se, assim, os dilemas envolvidos no julgado - a eugenia, o momento da personalidade jurídica do embrião e o princípio núcleo da constituição (dignidade da pessoa humana) - para facilitar a compreensão do tema ora proposto no presente trabalho.

Por fim, o ápice do tema de descartar embriões por razões eugênicas, o que afronta diretamente a dignidade da pessoa humana, trata o embrião como coisificação e causa a discriminação de ordem genética (este será abordado no item 4). A possibilidade de incentivo somente para reprodução de embriões "saudáveis", limitando ou excluindo a reprodução dos "que possuem anomalias", através do uso inadequado da técnica de diagnóstico genético do embrião, pré-natal ou pré-implantacional, acarreta na discriminação genética.

Apesar de tal fato poder implicar em crime de aborto, como também no tratamento genético do embrião, no Brasil não existe uma legislação mais específica para um adequado tratamento da matéria, permitindo, em virtude da lacuna legal, que os embriões sejam utilizados indiscriminadamente para pesquisa apenas com base na Lei da Biossegurança, o que, por vezes, ocasiona o emprego de técnicas antiéticas e contrárias aos ditames constitucionais. O mau uso da ciência, gerado pela falta de limites legais, pode implicar a inconstitucionalidade decorrente da discriminação genética. Há, portanto, a imprescindibilidade de sua regulamentação.

\section{Da recente decisão do Supremo Tribunal Federal acerca do embrião humano}

O Supremo Tribunal Federal - STF, em 2008, através da Ação Direta de Inconstitucionalidade - ADI no 3.510, declarou ser constitucional a Lei de Biossegurança, que permite o uso de embriões in vitro em pesquisas científicas com a finalidade terapêutica, desde que o embrião seja inviável ou esteja congelado há 3 (três) anos ou mais.

Esta decisão incorporou o constitucionalismo fraternal com o intuito de trazer a ideia da pesquisa científica do embrião longe da ofensa à dignidade da pessoa humana, à vida, à integridade física, mas perto de traduzir a comunhão de vida ao propiciar tratamento curativo e lenitivo de várias enfermidades congênitas com tendência a se desenvolver (BRASIL, 2010).

Diante da lacuna da lei quanto ao momento de início da vida humana, o nosso Texto Federal adota a teoria natalista, que reconhece a personalidade civil a partir do nascimento com vida e, consequentemente, os direitos, não confundindo, portanto, o embrião com pessoa humana e vice-versa, mas o entendendo 
como uma expectativa de vida, pois, para o pensamento de um grupo expressivo de cientistas, principalmente especialistas em neurociência, o embrião precisa desenvolver terminações nervosas para se the poder reconhecer o direito à vida (ANDRADE, 2012).

Assim, para a maioria dos julgadores dessa ADI no 3.510, com a incorporação do constitucionalismo fraternal, por se tratar de experimento in vitro, o embrião não desencadeia uma gestação igualmente humana e, por não ser um feto ou uma pessoa humana, não existe vida, e por não ser um ser vivo, é possível que seja experimento da ciência. Nesse sentido fundamenta o Ministro Celso de Mello (SUPREMO TRIBUNAL FEDERAL, ADI no 3.510):

Inexistência de ofensas ao direito à vida e da dignidade da pessoa humana, pois a pesquisa com células-tronco embrionárias (inviáveis biologicamente ou para os fins a que se destinam) significa a celebração solidária da vida e alento aos que se acham à margem do exercício concreto e inalienável dos direitos à felicidade e do viver com dignidade.

Cientificaram, ainda, que a pesquisa do embrião in vitro possui a finalidade terapêutica, propiciando aos portadores de doenças genéticas melhores condições de uma vida saudável, em nada contrapondo à Constituição Federal, pois ela não diz quando começa a vida humana e, quando menciona “dignidade da pessoa humana", refere-se meramente à pessoa humana a extensão dos direitos ali resguardados.

Expressaram, por fim, que o embrião é um bem tutelável pelo direito, mas não como direito à vida, de modo que as pesquisas com células-tronco embrionárias respeitam a livre expressão da ciência e, por conseguinte, o planejamento familiar, a paternidade responsável, que consiste na escolha do casal em implantar ou não todos os embriões.

Contrários ao fundamento da maioria, cinco ministros tentaram dar interpretação diversa à lei. O Ministro Menezes Direito proferiu o voto mais completo de discordância, com grande cautela jurídica, analisando desde os primórdios dos momentos para concepção da vida até uma profunda análise das técnicas de reprodução assistida, explicando as etapas, as técnicas e os grupos de embriões a que se chegam diante desta manipulação físico-química dos gametas.

Chega a diferenciar os embriões de boa qualidade, de média qualidade e os embriões inviáveis para fins de reprodução, enfatizando o descaso com os inviáveis que são simplesmente descartados como lixo biológico. 
Vota, minoritariamente, pela inconstitucionalidade da Lei de Biossegurança, por considerar a célula embrionária vida humana e qualquer uso diverso à sua destinação ato contrário ao direito à vida. Para Menezes Direito, a vida embrionária é uma potencialidade que não se desenvolverá diante das técnicas de reprodução assistida e, para atingir tal argumento, conota a potencialidade nos seguintes termos (BRASIL, 2008):

Tenha-se presente o comentário de Julián Marías mostrando em Aristóteles a divisão do ser segundo a potência e o ato, ao dizer que um "ente pode ser atualmente ou apenas uma possibilidade. Uma árvore pode ser uma árvore atual ou uma árvore em possibilidade, por exemplo uma semente. A semente é uma árvore, mas em potência, como a criança é um homem, ou o pequeno, grande. Mas é preciso ter em mente duas coisas: em primeiro lugar, não existe uma potência em abstrato, uma potência é sempre uma potência para um ato; isto é, a semente tem potência para ser carvalho, mas não para ser cavalo, nem sequer pinheiro, por exemplo; isso quer dizer, como afirma Aristóteles, que o ato é anterior (ontologicamente) à potência; como a potência é potência de um ato determinado, o ato já está presente na própria potencialidade" (História da filosofia. Martins Fontes, 2004, p. 75).

Com classe, desqualifica o voto do Ministro Relator Carlos Brito, mas, mesmo assim, seu voto é vencido, e o acórdão resulta da declaração de constitucionalidade da Lei de Biossegurança.

\section{Dos embates perante 0 julgado: eugenia $x$ personalidade jurídica $x$ dignidade da pessoa humana}

Diante dessa decisão do Supremo Tribunal Federal, importante se fazer esclarecer os dilemas envolvidos no julgado para melhor se compreender o tema ora proposto no presente trabalho.

\subsection{Da eugenia: conceito e especificações}

Atualmente, o termo eugenia está associado aos avanços biotecnológicos, tendo por núcleo a preocupação da saúde das novas gerações. Segundo Souza (2001, p. 57), eugenia é “a aplicação das leis biológicas da herança para o aperfeiçoamento da espécie humana”. Na visão de Oliveira (2004, p. 197), “eugenia 
é a disciplina/doutrina cujo objeto de estudo é as questões referentes ao "melhoramento' físico e mental do homo sapiens".

Cruzando o conceito de eugenia com o julgado da ADI no 3.510, a ideia é justamente incentivar a reprodução dos embriões "saudáveis" e limitar ou excluir a reprodução dos "que possuem anomalias".

Nesse sentido, Santos (2001, p. 174) retrata:

A manipulação genética de per se implicaria a possibilidade de os pais escolherem o sexo de seus bebês, troca de genes supostamente defeituosos por outros "sadios", escolhas de ordem estética, racial que, em última análise, comportaria uma forma de seleção artificial da espécie, e não se sabe quem poderia se julgar legitimado nesse mister (SANTOS, 2001, p. 174).

A problemática de se permitir as técnicas de manipulação genética sem regulamento legal para sua aplicação é o fato de elas visarem ao melhoramento e aperfeiçoamento da espécie humana para que só haja a reprodução de pessoas sadias, pouco se importando com a extinção de pessoas com tendência a desenvolver doenças congênitas.

Denota-se, portanto, que a eugenia possui duas facetas, uma positiva e outra negativa, da qual é possível visualizar os riscos do futuro da humanidade. É através dessa positividade que se permite escolher as competências humanas, tais como a inteligência, a criatividade, as características psicofísicas, a memória, entre outras, eliminando os genes considerados indesejáveis, permitindo, na análise das técnicas de reprodução assistida, orientar os casais a procriar seres humanos geneticamente aptos (SILVA, 2002, p. 310).

Simone Oliveira (2006, p. 124) assim aborda: "Seja a eugenia positiva aquela em que há a transmissão dos genes desejáveis”. Nesse sentido, corrobora Fátima Oliveira (1997, p. 111), que é "aquela que aspira à reprodução de humanos cada vez mais vigorosos, aptos e perfeitos".

Por outro lado, a faceta negativa consiste na eliminação de gerações incapazes (doentes, raças, indesejáveis e empobrecidos). Ela ocupa-se da prevenção e cura de doenças e malformações genéticas. A ideia é justamente diminuir o número de pessoas disgênicas, através da proibição de casamento e das técnicas de reprodução assistida, como, por exemplo, em caso de idade avançada ou de consanguinidade do casal e esterilização (ANGERAMI; MAI, 2006, p. 254).

Nessa seara, Varga (1998, p. 78) conclui ser "a eugenia negativa aquela que visa eliminar os defeitos genéticos. Assim sendo, os seres considerados 'inferiores' não poderão transmitir seus defeitos aos seus descendentes". 
A diferença consubstancial das facetas é que a positiva visa ao melhoramento e ao aperfeiçoamento da espécie humana, e a negativa visa prevenir a reprocriação de seres com "defeitos genéticos".

Ambas as facetas são preocupantes e causam riscos de extinção da espécie de portadores de genes defeituosos. Em diversos países, já houve e, em alguns, ainda há a prática da eugenia, como já houve na Alemanha sob Hitler, quando se procedeu à segregação, esterilização, eutanásia e extermínio em massa dos “indesejáveis”, e ainda há, na China, através da Lei de 1995, que prevê exames pré-nupciais para o controle de doenças genéticas, infecciosas ou mentais (DIWAN, 2007, p. 6).

Apesar de, no Brasil, a Constituição Federal obrigar o Poder Público a preservar a diversidade e a integralidade do patrimônio genético em seu art. 225, a prática da eugenia negativa torna-se visível nos dias de hoje. Através das técnicas de reprodução assistida, é possível detectar anomalias no gene de um embrião e descartá-lo se for possuidor de uma característica defeituosa.

Assim, uma vez que a ADI no 3.510 foi declarada constitucional e não há outra regra legal para regulamentar o assunto, torna-se possível utilizar-se de embriões para pesquisa científica com a finalidade terapêutica, permitindo-se, assim, por meio das técnicas de reprodução assistida e do diagnóstico genético de préimplantação, descartar embriões por razões eugênicas, afrontando diretamente a dignidade da pessoa humana, eis que passa a tratar o embrião como coisificação.

Por mais que consideremos positiva a finalidade da pesquisa terapêutica para a sociedade, ao fornecer melhores condições de subsistência humana, a utilização de embriões que são descartados por possuírem algum gene defeituoso deve ser associada a uma prática inconstitucional, uma afronta à dignidade da pessoa humana, ao compreender o embrião como uma potencialidade de vida, a qual se passe adiante abordar.

\subsection{Do momento da personalidade jurídica do embrião}

A personalidade jurídica está intimamente ligada ao termo pessoa. Este instituto é um atributo dado à pessoa para a qual o direito passa a reconhecê-la como titular de direitos e obrigações, sendo, portanto, um atributo necessário para ser sujeito de direitos, tornando-se, assim, imprescindível abordar o conceito de pessoa.

Atualmente, não há um consenso na doutrina sobre o que é pessoa, nem mesmo sobre a sua origem; contudo, a maioria dos doutrinadores compreende que o pensamento antigo desenvolveu e aprofundou a realidade humana com o 
surgimento do vocábulo latino persona. Nessa época, trazia-se a ideia de uma máscara utilizada por atores, vindo posteriormente o termo a ser empregado para determinar o próprio papel desempenhado pelos intérpretes e, por conseguinte, contextualizado para designar a atuação de cada indivíduo no panorama jurídico, já que, na sociedade, cada indivíduo desempenhava um papel, do mesmo modo que os atores no teatro (GONÇALVES, 2008, p. 20-21).

Apesar de o julgado sobre a Lei de Biossegurança ter ora o intento jusnaturalista, ora positivista de buscar uma resposta dogmática, houve ilações sobre o que é pessoa no sentido naturalista. O Ministro Carlos Ayres de Brito (STF 2010, p. 65 e 182) confirma esta posição, ao assim comentar sobre o embrião in vitro:

Donde até mesmo se presumir que sem ele, aparato neural, a própria alma já não tem como cumprir as funções e finalidades a que se preordenou como hóspede desse ou daquele corpo humano. (Grifo nosso)

$[\ldots]$

É um embrião que não corresponde jamais ao conceito de nascituro. Não há nascituro, muito menos alma. É de se supor que a alma vem ao mundo para cumprir uma função e ela é inteligente o suficiente para não ficar confinada em um vidrinho, sob a forma de embrião.

Contudo, tal análise ultrapassa questões filosóficas, culturais, pessoais e religiosas, que não cabe discutir neste ensaio. A relevância deste tópico está interligada à discussão sobre o início da proteção ao direito à vida ao embrião in vitro.

Infelizmente, como a nossa Constituição Federal não diz quando começa a vida humana, para muitos ela se inicia com a fecundação ${ }^{2}$ e, para outros, a concepção ${ }^{3}$ seria a origem da personalidade. Contudo, de acordo com o Código Civil, a personalidade civil da pessoa começa com nascimento com vida, mas a lei põe a salvo desde a concepção os direitos do nascituro.

2 Essa pergunta é fundamental, pois os dois conceitos, fecundação e concepção, embora muito diferentes sob a perspectiva médica, são usados equivocadamente como sinônimos. A fecundação, também chamada de fertilização, refere-se, exclusivamente, ao processo de união dos gametas masculino e feminino, óvulo e espermatozoide (MINISTÉRIO DA SAÚDE, 2011, p. 27-29).

3 O conceito de concepção se aplica ao processo de nidação. A fecundação ocorre muito antes da implantação ou nidação. Ambos não são sinônimos e não devem ser confundidos. Somente a partir do momento da concepção é que ocorrerá o desenvolvimento do polo embrionário do blastocisto, que resultará no embrião. Até atingir esse ponto do processo reprodutivo, as taxas de sucesso são baixas. Menos de $50 \%$ das relações sexuais em período fértil terminam em fecundação e metade desses zigotos perde-se naturalmente, sem que ocorra a implantação. Essa é uma característica da reprodução da espécie humana, que restringe a possibilidade de gravidez a cerca de 20 a $25 \%$ em cada mês de tentativa (MINISTÉRIO DA SAÚDE, 2011, p. 27-29). 
O julgado do Supremo Tribunal Federal defendeu a teoria de que o nascituro é apenas uma mera expectativa de direito e, por tal razão, é uma mera expectativa de pessoa. Contudo, o Ministro Menezes Direito, em seu brilhante voto, relata a potencialidade do embrião, de modo que este não seria apenas uma expectativa de pessoa, mas, sim, uma potencialidade de pessoa (SUPREMO TRIBUNAL FEDERAL, 2010).

De acordo com a percepção da genética, proposta mais aceita oficialmente pela Igreja Católica, a vida humana tem início com a fecundação, isto é, "quando o óvulo e o espermatozoide se encontram e formam um novo conjunto genético que origina um ser único" (SEQUEIROS; BENTO, 2013). Teles (2004 apud SERQUEIROS; BENTO, 2013) complementa ao afirmar que o "embrião adquire identidade genética, e tendo em conta que o patrimônio genético pertence a uma espécie, o embrião humano deve ser considerado como um ser humano".

Ainda, mais do que isso, o Ministro Menezes Direito realça a teoria de Habermas, ${ }^{4}$ de que nós somos um corpo e não temos um corpo, de modo que este corpo, juntamente com suas características, sua "biografia", se inicia no momento da fecundação, não havendo como precisar um momento mais importante (da fecundação ao nascimento):

Um dos principais argumentos em contrário é amparado em estudos que indicam haver diversos estágios contínuos no processo de desenvolvimento embrionário e fetal, não sendo possível isolar as etapas e, portanto, considerar algumas mais importantes que outras (STF, 2010, p. 124).

É claro que o critério biológico é muito parco para uma conceituação ampla de pessoa, como já explanado; contudo, é possível defender que este mínimo (ser biologicamente humano) e o seu marco inicial (fecundação) são fatores idôneos para o começo da proteção jurídica da pessoa humana.

É evidente a força de conceitos filosóficos e psicológicos para a caracterização da personalidade jurídica, pois há seres que não possuem tais condições, mas devem ser protegidos, de modo que, havendo desde já a fecundação, há também potencialidade de vida, não podendo um embrião ser descartado/destruído por possuir uma característica diversa de um DNA considerado saudável.

\footnotetext{
Uma pessoa só "tem" ou "possui" seu corpo (Körper) na medida em que ela "é" esse corpo vivo (Leib) - na realização da sua vida. Partindo desse fenômeno de ser e ter um corpo ao mesmo tempo, Helmuth Plessner descreveu e analisou em sua época a "posição excêntrica" do homem. Conforme mostra a psicologia cognitiva do desenvolvimento, ter um corpo é apenas o resultado de uma capacidade, adquirida na juventude, de contemplar de forma objetivante o ser-um-corpo-vivo em seu processo. 0 modo de experenciar esse corpo vivo é primário e, “dele”, também vive a subjetividade da pessoa humana (HABERMAS, 2010, p. 70).
} 
A bioética, o ramo que estuda a moralidade da conduta humana no campo das ciências da vida, leva em consideração os problemas éticos que surgem com as descobertas científicas à luz da moralidade e da ética, buscando sempre para que seja respeitada a dignidade da pessoa humana.

Assim, ao tratar do descarte ou destruição de um embrião, foi possível deparar com um problema ético e moral a partir do momento em que passa a considerar o embrião como potencialidade de vida desde a fecundação. Diversos operadores das técnicas médicas (médicos, pesquisadores e doutores) consideram o embrião como potencialidade de vida (derivante do entendimento do início da vida desde a fecundação), e descartá-lo ou destruí-lo seria submeter uma vida humana à morte. O Dr. Carlos Gilberto Almodin, da Clínica Mater Baby de Maringá, médico e grande pesquisador das técnicas que envolvem a reprodução assistida, relata que o embrião é uma vida, bem como que jamais pretende submeter uma vida humana à morte. Em passado recente, relata que a Suprema Corte permitiu clínicas da Inglaterra, que entraram na justiça pedindo para descartar embriões que não seriam mais utilizados (devido ao alto custo financeiro de armazenamento), descartarem metade dos embriões, e a outra metade deveria ser usada em pesquisas, posicionamento represado pelo médico doutor (MAFFI, 2010).

Em sua clínica, o i. Doutor Carlos G. Almodin, por não consentir com o descarte, muito menos a destruição de um embrião, havendo embriões disponíveis, passam-se estes por processo de doação. O médico relata não ser rara a desistência de casais quanto à reprodução por meio de técnicas assistidas, nem mesmo a sobra de embriões não implantados e, por tal motivo, ficam esses disponíveis para doação, pois, conforme seus dizeres, jamais submeteria uma vida humana à morte (MAFFI, 2010).

Não se pode deixar de enxergar a gravidade do cenário pelas técnicas de diagnóstico genético de embriões, em que se torna possível selecionar aqueles não possuem anomalias e descartar os defeituosos genéticos. Essa prática desenfreada em busca da eugenia, do ser humano programado em laboratório, não pode deixar de ser cenário de reflexão pelo mundo do direito e, por este motivo, desenvolve-se o presente trabalho, principalmente por consentir com o entendimento de Menezes Direito, de que a vida se principia com a fecundação, tornando os embriões potencialidade de ser pessoa humana.

\subsection{Do núcleo da Constituição: dignidade da pessoa humana}

Como dito anteriormente, todo dilema entre o direito à vida e a dignidade do embrião in vitro advém da imprecisão do início da personalidade jurídica. Em prol 
da minoria dos julgadores da ADI no 3.510, não há como precisar o momento mais importante do início da vida, mas, com certeza, a fecundação principia este ciclo, como já retratado no item 3.2.

Desta forma, não há como o avanço da biotecnologia desrespeitar as fases de formação de um embrião, de modo que, ao basear-se em princípios éticos para realizar pesquisas, deve sustentar o princípio mais relevante entre eles, qual seja, o princípio da dignidade da pessoa humana.

O princípio da dignidade da pessoa humana é o primeiro e o mais importante princípio do sistema jurídico brasileiro (SZANIAWSKI, 2005, p. 140), bem como de uma parte dos países, mas ainda não possui uma conceituação uniforme e universal no âmbito de proteção como norma jurídica fundamental. Atualmente, a maioria das definições obtidas de dignidade da pessoa humana tem sido vaga e imprecisa em virtude de sua natureza polissêmica (SARLET, 2007, p. 363-364).

Contudo, a conceituação clássica não paira dúvidas da dimensão ontológica da dignidade ao atribuir-lhe como uma qualidade intrínseca da pessoa humana, pois "está, portanto, compreendida como qualidade integrante e, em princípio, irrenunciável da própria condição humana [...] já que existe - ou é reconhecida como tal - em cada ser humano como algo que lhe é inerente", caracterizado pela própria natureza humana (SARLET, 2007, p. 365).

Suplementando esta concepção, expõe Szaniawski (2005, p. 141):

[...] a ideia de que todo ser humano é possuidor de dignidade é anterior ao direito, não necessitando, por conseguinte, ser reconhecida juridicamente para existir. Sua existência e eficácia não precisam vir expressas no ordenamento jurídico. No entanto, dada a sua importância, vem sendo, de longa data, reconhecida pelas legislações dos povos democráticos como princípio jurídico fundamental.

Para tanto, Sarlet (2007, p. 365) retrata a necessidade de destacar as dimensões da dignidade da pessoa humana para alcançar sua compreensão como núcleo da ordem jurídica constitucional, o que, de modo imprescindível, impõe relacionar algumas em virtude do tema proposto neste trabalho.

As dimensões evidenciadas na obra de Sarlet (2007) complementam-se e interagem-se mutuamente, no estado constitucional e cultural, reduzindo-se a dignidade de todo e qualquer ser humano, independentemente de sua condição pessoal e concreta:

[...] aquele que nada "presta" para si próprio ou para os outros (de tal como ocorre com o nascituro, o absolutamente incapaz, etc.) evidentemente não deixa de ter dignidade e, para além disso, não deixa de ter o direito de vê-la respeitada e protegida. 
É possível notar que o conceito de dignidade humana é evolutivo, dinâmico e abrange os gêneros humanos pertencentes na comunidade, assim como os diversos valores existentes na sociedade. Exemplo disso é a Conferência de Direitos Humanos de Viena, que afirmou os direitos das mulheres como direitos humanos (BARCHIFONTAINE, 2010).

Essa ampliação do conceito de dignidade possui uma conduta ética social, que se funda no reconhecimento social, devendo ser compreendida como uma categoria do próximo, e não somente como uma qualidade do ser humano (BARBEDO).

E com os embriões humanos não deve ser diferente. O embrião humano tem direitos fundamentais pelo que deverá ter proteção adequada dada a dignidade que Ihe é intrínseca. Nesse sentido, dispõe a Convenção sobre os Direitos do Homem e da Biomedicina, em seu art. 18, no 1: "Quando a pesquisa de embriões in vitro é admitida por lei, esta garantirá uma proteção adequada ao embrião"; e em seu art. 18, no 2: “A criação de embriões humanos com fins de investigação é proibida” (SEQUEIROS; BENTO, 2013).

Assim, ante a abordagem de sua dimensão dúplice (compreendida pela autonomia da pessoa humana - autodeterminação - e pela proteção - assistência - por parte do Estado e da comunidade), a dignidade passa a ser entendida, para aqueles que Ihes faltarem as condições para uma decisão própria, como protecional e assistencial (SARLET, 2007, p. 376).

Já dizia Dworkin (1998, p. 306-307) que, em determinadas circunstâncias, o ser humano deve receber um tratamento digno. Neste ponto de vista, afirma Sarlet (2007, p. 378):

[...] seguindo uma tendência que parece estar conduzindo a uma releitura e recontextualização da doutrina de Kant (ao menos naquilo em que aparentemente se encontra centrada exclusivamente na noção da autonomia da vontade racionalidade), vale reproduzir a lição de Dieter Grimm, eminente publicista e Magistrado germânico, ao sustentar que a dignidade, na condição de valor intrínseco do ser humano, gera para o indivíduo o direito de decidir de forma autônoma sobre seus projetos existenciais e felicidade e, mesmo onde esta autonomia Ihe faltar ou não puder ser atualizada, ainda assim ser considerado e respeitado pela sua condição humana.

Com base no que até agora foi exposto, constitucionalmente falando, toda pessoa humana tem uma dignidade própria e constitui valor em si mesmo, de modo que não pode se sujeitar a qualquer afronta coletiva (FERREIRA FILHO, 1980, 
p. 19), muito menos ser tratada como objeto, coisa ou instrumento (SARLET, 2007, p. 380).

Apesar de não se descartar a existência da vida humana desde a fecundação, defendida por muitos pesquisadores, doutores e cientistas, o tratamento jurídico atual dado ao embrião é diverso, pois depende de como é considerada a sua natureza, coisa ou pessoa. Como bem consignou Sarlet (2007, p. 380) ao citar Michael Sachs, “tal fórmula parte de uma definição da dignidade considerando seu âmbito de proteção, traduzindo uma opção por uma perspectiva que prefere determinar este âmbito de proteção a partir de suas violações no caso concreto", concluindo, ao final, que:

[...] onde não houver respeito pela vida e pela integridade física e moral do ser humano, onde as condições mínimas para uma existência digna não forem asseguradas, onde não houver limitação do poder, enfim, onde a liberdade e a autonomia, a igualdade (em direitos e dignidade) e os direitos fundamentais não forem reconhecidos e minimamente assegurados, não haverá espaço para a dignidade da pessoa humana e esta (a pessoa), por sua vez, poderá não passar de mero objeto de arbítrio e injustiças (SARLET, 2007, p. 380-381).

Reportando à doutrina de Dworkin (1998, p. 307-310), já citado anteriormente, a pessoa não pode ser tratada como objeto, pois, se assim ocorrer, negar-se-á a importância da própria vida. Ademais, coisificar alguém, nos termos propostos por Sarlet (2007, p. 382), é violar a dignidade da pessoa humana.

Compartilhando do pensamento de Menezes Direito, que obteve seu voto vencido diante do julgamento da $A D I$ no 3.510, compreende-se que o embrião in vitro é uma potencialidade de vida, pois o início da vida humana principia com o instante da fecundação e fertilização e, portanto, o descarte ou destruição desse embrião após a técnica do Diagnóstico Genético Pré-Implantacional devido à utilização de apenas embriões saudáveis importaria na violação do direito à vida e, por tal razão, não há como Ihe negar a sua individualidade de condição humana, ${ }^{5}$ de modo que não há como lhe negar o direito à vida, principalmente à dignidade,

5 Cf. ARENDT, Hannah. A condição humana. Tradução de Roberto Raposo, posfácio de Celso Lafer. 10. ed. Rio de Janeiro: Forense Universitária, 2007, p. 17. Para a autora, "a condição humana compreende algo mais que as condições nas quais a vida foi dada ao homem. Os homens são seres condicionados: tudo aquilo com o qual eles entram em contato torna-se imediatamente uma condição de sua existência. 0 mundo no qual transcorre a vida activa consiste em coisas produzidas pelas atividades humanas; mas, constantemente, as coisas que devem a sua existência exclusivamente aos homens também condicionam os seus autores humanos. [...] o que quer que toque a vida humana ou entre em duradoura relação com ela, assume imediatamente o caráter de condição da existência humana [...] tudo o que espontaneamente adentra o mundo humano, ou para ele é trazido pelo esforço humano, torna-se parte da condição humana". 
como uma valoração de sua existência humana, eis ser digno de existência como qualquer outro ser humano, seu entendimento resume-se em: "Não tivemos um embrião, e sim um dia fomos um embrião" (SUPREMO TRIBUNAL FEDERAL, ADI no 3.510).

Apesar da singularidade da decisão de Menezes Direito, a compreensão de que embrião in vitro é uma potencialidade de vida não pode ser desconsiderada. De fato, todos um dia fomos um embrião e, sem sombras de dúvidas, a existência da espécie humana inicia-se embrionariamente, naturalmente concebidos por embriões saudáveis e por embriões portadores de doenças congênitas.

A dignidade humana prevista constitucionalmente subsiste da espécie humana, é inerente à condição humana, sem se importar com a forma como ela seja ou se desenvolva, protegendo como um todo a espécie humana. Portanto, a proteção constitucional se vale para aqueles considerados pessoa humana, assim como se funda no reconhecimento social protegendo a comunidade. Segundo Barchifontaine (2010), “essa posição não reconhece diferença de estatuto moral entre os diversos estados de desenvolvimento humano (embrião, feto, recém-nascido, criança, adulto...). Desde a concepção, o óvulo fertilizado se torna membro da comunidade moral humana". Incluem-se, portanto, os embriões geneticamente modificados, ou seja, aqueles portadores de alguma anomalia genética.

Permitir a exterminação de embriões com genes modificados e torná-los somente objeto de pesquisa devido à busca desenfreada pela eugenia (melhoramento e aperfeiçoamento da espécie humana) desvaloriza a espécie humana e afeta a integridade física e psíquica dos portadores de alguma anomalia que vivem em sociedade. Trata-os como coisificação, ou seja, somente como objeto alvo de descobertas para os genes serem apenas saudáveis, o que pode acarretar a extinção daqueles que tanto lutaram por inclusão social, educacional e familiar sem qualquer tipo de preconceito ou distinção.

\section{Do diagnóstico genético pré-implantacional e o dilema da eugenia à luz da discriminação genética}

Diante da conceituação de eugenia no item 3.1, entrelaçada ao julgado da ADI n 3.510 dado pelo Supremo Tribunal Federal em 2005, pode-se extrair a ideia de incentivar somente a reprodução dos embriões "saudáveis" e limitar ou excluir a reprodução dos “que possuem anomalias". É através do uso inadequado da técnica de diagnóstico genético do embrião, pré-natal ou pré-implantacional, que decorrem essas reproduções e, por conseguinte, advém a discriminação genética. 
Esta técnica de manipulação genética submete o embrião ao exame genético de precaução em busca de anomalias, seja daquele que já se encontra no ventre materno (diagnóstico de pré-natal), seja daquele que será implantado no útero (diagnóstico pré-implantacional), como ocorre na fertilização in vitro. Para melhor esclarecimento, transcreve-se a conceituação dada em artigo publicado na Federação Brasileira de Ginecologia e Obstetrícia:

Tradicionalmente, a prevenção das anomalias genéticas cromossômi-
cas em pacientes de alto risco é realizada por exames pré-natais,
como a biópsia do vilo coriônico, aminiocentese e a cordocentese.
Uma vez diagnosticada a anomalia, não existe tratamento eficaz para
portadores de aberrações genéticas e a interrupção da gestação nes-
tes casos ainda é ética e legalmente questionável. O diagnóstico ge-
nético pré-implantacional (DGPI) representa uma ferramenta valiosa
aos casais de alto risco, por permitir a seleção de embriões saudáveis
obtidos através de programas de fertilização in vitro antes de estes
serem transferidos para um útero materno (WOLFF; MARTINHAGO;
UENO, 2009, p. 297).

A conceituação apresentada demonstra o intuito benevolente da técnica medicinal para auxiliar casais à procriação, sobretudo para casais de alto risco; contudo, as consequências negativas desta técnica merecem ser pauta de reflexão ao tratar da condição do embrião in vitro.

A faceta negativa desse tipo de análise decorre do fato de poder se escolher um embrião saudável e descartar os demais embriões, aqueles que possuem potencialidade vital, mas, por atribuírem alguma anomalia cromossômica, acabam sendo descartados.

A doença cromossômica mais conhecida é a Síndrome de Down; todavia, a maioria dos portadores dessa doença, fisicamente falando, é igual aos seres humanos perfeitamente desenvolvidos, possuindo apenas algumas restrições mentais, não sendo um obstáculo para a maioria deles se desenvolverem e se adaptarem ao meio social. Inclusive, recentemente, a primeira professora com Síndrome de Down foi digna de matéria jornalística por receber prêmio de educação. E sabe qual a diferença entre ela e os outros docentes? É que Débora tem Síndrome de Down (UNIVERSIA BRASIL, 2015).

Portanto, ao permitir se descartar um embrião que for diagnosticado ser portador de Síndrome de Down pela técnica de DGPI, está se descartando ou destruindo um embrião com potencialidade de vida, digno de existência como qualquer outro ser humano. 
Ademais, as técnicas de reprodução assistida que existem (fertilização in vitro, inseminação artificial, entre outras) facilitam casais de alto risco a procriarem, e esse deveria ser o único intuito, e não permitir que se possibilite escolher quem vive ou quem morre. Uma doença cromossômica que permite o indivíduo desenvolver-se, viver e adaptar-se ao meio social não pode ser considerada uma aberração genética passível de descarte e/ou destruição.

A primeira aplicação clínica do diagnóstico genético pré-implantacional ocorreu em 1990, na qual se descreveu a sexagem de um embrião com risco de doença ligada ao sexo (WOLFF; MARTINHAGO; UENO, 2009, p. 298).

Apesar de os princípios do Conselho Federal de Medicina estabelecerem que a técnica de reprodução assistida não pode ser aplicada com a intenção de escolha de sexo ou qualquer outra característica biológica do futuro de filho que venha a nascer (CFM, Res. no 1.957/2010), ela é utilizada em busca do aperfeiçoamento do ser humano.

Na prática médica, em geral, o objetivo e as indicações do DGPI para estudos "têm justificação desde que estejam disponíveis recursos que permitam intervir a nível terapêutico, preditivo ou preventivo, e assim salvar vidas, curar, aliviar o sofrimento humano ou prevenir o desenvolvimento de doenças" (CNECV, 2007, p. 5).

A princípio, a técnica de DGPI era utilizada em famílias em relação às quais já se conhecia uma mutação com o intuito de evitar a transmissão hereditária de anomalia genética (ligadas ao cromossomo X) ou anomalia cromossômica estrutural; contudo, nos dias atuais, ela tem sido usada, cada vez mais, para apoio à procriação da reprodução assistida, com a finalidade de vasculhar os genes dos embriões gerados em famílias em que não há prévio conhecimento de risco genético, justamente com o intuito de avaliar a qualidade dos embriões produzidos in vitro.

É por meio da realização de exames, como o FISH (Fluorescent "In Situ" Hibridization) para diagnóstico de patologias cromossômicas e o PCR (Polimerase Chain Reaction) para detecção de patologias gênicas (WOLFF; MARTINHAGO; UENO, 2009, p. 298), que o embrião é selecionado e, se ele possuir algum tipo de anomalia em seu gene, é descartado pelo simples fato de ser portador de defeito genético.

Esse tipo de técnica, querendo ou não, põe em prática a eugenia liberal com afronta direta à Constituição, em especial em seu art. 3ำ, inciso $\mathrm{IV}^{6}{ }^{6}$ que

6 Art. 3ำ Constituem objetivos fundamentais da República Federativa do Brasil: I - construir uma sociedade livre, justa e solidária; II - garantir o desenvolvimento nacional; III - erradicar a pobreza e a marginalização e reduzir as desigualdades sociais e regionais; IV - promover o bem de todos, sem preconceitos de origem, raça, sexo, cor, idade e quaisquer outras formas de discriminação. 
claramente proíbe incidência de "qualquer forma de discriminação"; no caso, a discriminação de origem genética.

Nos dizeres de Francisco Vieira Lima Neto (2004, p. 85), a discriminação genética é compreendida como:

[...] um tratamento diferencial de indivíduos ou seus parentes consangüíneos baseado na sua atual ou presumida diferença genética em relação aos outros seres humanos e que decorre do fato de apresentarem sintomas de uma doença de origem genética ou da possibilidade de virem a apresentar determinado comportamento social ou característica "não desejável" (subversão, indolência, excesso ou falta de inteligência, homossexualidade, obesidade, etc.), que seria decorrente da suposta e automática submissão do ser humano aos comandos provenientes de seus genes.

É evidente que o processo de discriminação genética está intimamente relacionado ao uso inapropriado, visto que, com a evolução do avanço biotecnológico, é perfeitamente possível escolher qual embrião viverá, pois só haverá seleção para procriar daquele com condição genética saudável.

Por sua vez, os embriões entendidos por inviáveis, diante dessa técnica de manipulação genética, acabam sendo excluídos do ciclo vital por causa de uma eugenia liberal permitida, pois não há regulamentação de proteção jurídica específica dos embriões. Pelo contrário, houve constitucionalidade da Lei de Biossegurança, que permite o uso desses embriões para finalidade terapêutica, consequentemente para uso de técnicas de manipulação genética, que acabam eliminando os portadores de doenças genéticas.

\section{Considerações finais}

Por todo o exposto, conclui-se que o avanço biotecnológico permite a realização de exames e procedimentos, especificamente direcionados à verificação de existência de anomalias hereditárias, capazes de serem realizados em qualquer etapa da vida, inclusive na fase gestacional, sem qualquer limitação em suas pesquisas, acarretando a discriminação de ordem genética e consequências nefastas à população.

Apesar de a Constituição Federal de 1988 resguardar que todos os seres humanos são iguais perante a lei, sem qualquer distinção de raça, cor, sexo, idade ou quaisquer práticas de discriminação, ainda tal ato é abertamente praticado, sem limitação, devido à falta de previsão legal. 
Apurou-se no presente estudo que os avanços tecnológicos têm proporcionado, em face das pesquisas realizadas, a indevida utilização de técnicas de manipulação genéticas antiéticas e contrárias aos ditames constitucionais, provocada pela ausência de limites legais específicos que delimitem a autonomia das pesquisas científicas e promovam o bem-estar de todos.

Hoje, o embrião cultivado por meio da técnica de fertilização in vitro e que possui tendência à doença genética é descartado, sendo utilizado apenas como objeto de pesquisa terapêutica, de forma ilimitada, à procura do melhoramento e aperfeiçoamento da espécie humana considerada saudável.

Esse comportamento evidencia-se tanto em relação aos embriões já concebidos como àqueles embriões ainda em desenvolvimento, uma vez que estes não são apenas células, mas apresentam a viabilidade de se tornarem seres humanos. Conclui-se que eles não deixam de se tornar pessoas humanas pela simples razão de serem portadores de doenças hereditárias ou portadores de deficiência.

De uma forma ou de outra, essa prática (de uso inapropriado da técnica de manipulação genética) incorre na discriminação genética dos embriões em que se diagnostica, por exemplo, a trissomia do cromossomo 21, como se os portadores de Síndrome de Down não tivessem o direito de viver.

Ignorar a existência dos seres portadores de deficiência congênita ou não permitir o desenvolvimento de embriões humanos diagnosticados com anomalia em seu gene é possibilitar a extinção dessa espécie humana digna de existência como qualquer outra.

Permitir a exterminação dos seres geneticamente modificados devido a faIhas em seu código genético é retroceder a existência da espécie humana, violar a dignidade do embrião e afrontar a vida física e psíquica dos seres deficientes existentes, que lutam por anos por uma inserção social digna e se deparam com uma guerra pelo extermínio de sua existência.

A falta de limite legal permite a utilização de embriões considerados indesejáveis para fins de pesquisa terapêutica, de modo ilimitado e indiscriminado, podendo ocasionar diversos impactos sociais e na vida privada desses indivíduos geneticamente modificados. Moderar a prática dessas pesquisas terapêuticas com embriões, seja por considerar os embriões como potencialidade de vida, seja por considerar a existência dessa espécie humana com deficiência, atinge a forma mais digna de buscar o melhoramento e o aperfeiçoamento da espécie humana, tornando-se, portanto, imprescindivel a sua regulamentação.

Sem lei específica para proibir tal prática, a busca desenfreada da eugenia, da raça pura e do ser humano programado em laboratórios acaba sendo a evidência 
desumana dos avanços da tecnologia, sem que haja o respeito à igualdade, à ética e, principalmente, ao ideal para a humanidade.

Recebido em: 15.09.2015.

Pareceres: 03.12.2015, 16.02.2016 e 19.08.2016.

Aprovado em: 14.12.2016.

\title{
Pre implantation genetic diagnosis in the light of genetic discrimination
}

\begin{abstract}
The scientific advances of recent years has increasingly allowed the use of new technologies and, more recently, we intend to make use of embryonic stem cells for obtaining treatment in order to recover bodies of people with disabilities, sick or who have suffered misfortunes. In Brazil, the ordinary legislature, with the Biosafety Law, allowed the use of embryos in vitro to develop scientific research. The Supreme Court accepted the constitutionality of this legislation, but properly for the development of research for therapeutic purposes. Research went on to develop several techniques and one of them is the genetic diagnosis of the embryo, which can be prenatal or preimplantation. This technique of genetic manipulation, related to in vitro fertilization, allows you to diagnose diseases and other features that allows parents to choose one of several embryos to be implanted, discarding or freezing the other. Through laboratory tests, such as FISH (Fluorescent "In Situ" Hybridization) for diagnosis of chromosomal disorders and the PCR (Polymerase Chain Reaction) for the detection of genetic disorders, it is possible to genetically select those with no abnormality in its gene and discard the rest, because carriers of genetic defect. This practice of genetic discrimination means that you can discard those embryos in which it is diagnosed, for example, trisomy 21, as those with Down syndrome did not have the right to live. No specific law to prohibit this practice, the unbridled pursuit of eugenics, pure race, the human being programmed in laboratories, ends up being the inhuman evidence of advances in technology, they need urgently act upon equality, ethics, and especially with the ideal for humanity.
\end{abstract}

Keywords: Biosecurity. Embryo. Genetic discrimination.

Summary: 1 Introduction - $\mathbf{2}$ From the recent decision of Supreme Court about embryo human $\mathbf{- 3}$ Before the clashes judged: eugenie $\mathrm{x}$ legal personality $\mathrm{x}$ human dignity $\mathbf{- 4}$ From preimplantation genetic diagnosis and the dilemma of eugenics in the light of genetic discrimination - $\mathbf{5}$ Final considerations - References

\section{Referências}

ANDRADE, Ana Marisa Carvalho de. Considerações jurídicas acerca do início da vida humana. 2012. Disponivel em: <http://jus.com.br/artigos/21637/consideracoes-juridicas-acerca-doinicio-da-vida-humana>. Acesso em: 10 dez. 2014.

ANGERAMI, Emília Luigia Saporiti; MAI, Lílian Denise. Eugenia negativa e positiva: significados e contradições. Disponivel em: <http://www.scielo.br/pdf/rlae/v14n2/v14n2a15.pdf>. Acesso em: 15 dez. 2014. 
ARENDT, Hannah. A condição humana. Tradução de Roberto Raposo, posfácio de Celso Lafer. 10. ed. Rio de Janeiro: Forense Universitária, 2007.

BARBEDO, Claudia Gay. O descarte ou a destruição de embriões excedentes e a anomia existente. Disponível em: <http://www.amprs.org.br/arquivos/revista_artigo/arquivo_1273861152. pdf>. Acesso em: 17 set. 2016.

BARCHIFONTAINE, Christian de Paul de. Bioética no início da vida. Revista Pistis Prax. Teol. Pastor., Curitiba, v. 2, n. 1, p. 41-55, jan./jun. 2010.

BRASIL. Constituição da República Federativa do Brasil de 1988. Disponível em: <http:// www.planalto.gov.br/ccivil_03/constituicao/constituicaocompilado.htm>. Acesso em: 05 jan. 2015.

BRASIL. Conselho Federal de Medicina. Resolução no 1.957 de 15 de dezembro de 2010. Disponível em: <http://www.portalmedico.org.br/resolucoes/CFM/2010/1957_2010.htm>. Acesso em: 05 jan. 2015.

BRASIL. Conselho Nacional de Ética para as Ciências da Vida. Relatório no 51 sobre "Diagnóstico Genético Pré-implantação". 2007. Disponível em: <http://www.cnecv.pt/ admin/files/data/docs/1273054214_P051_RelatorioDGPI.pdf>. Acesso em: 05 jan. 2015.

BRASIL. Ministério da Saúde. Anticoncepção de emergência: perguntas e respostas para profissionais de saúde. Disponível em: <http://bvsms.saude.gov.br/bvs/publicacoes/ anticoncepcao_emergencia_perguntas_respostas_2ed.pdf>. Acesso em: 18 dez. 2014.

DIWAN, Pietra. Eugenia, a biologia como farsa. Disponível em: <http://www.portaldo envelhecimento.org.br/artigos/artigo3182.htm>. Acesso em: 02 dez. 2014.

DWORKIN, Ronald. El domínio de la vida: una discusión acerca del aborto, la eutanasia y la liberdad individual. Barcelona: Ariel, 1998.

FERREIRA FILHO, Manoel Gonçalves. Direitos Humanos Fundamentais. São Paulo: Saraiva, 1980.

GONÇALVES, Diogo Costa. Pessoa e direitos de personalidade: fundamentação ontológica da tutela. Coimbra: Almedina, 2008.

HABERMAS, Jürgen. O futuro da natureza humana. 2. ed. São Paulo: Martins Fontes, 2010.

LIMA NETO, Francisco Vieira. Ética, mapeamento de DNA e discriminação genética: novos desafios da pós-modernidade. In: LEITE, Eduardo de Oliveira (Coord.). Grandes Temas da Atualidade. Bioética e Biodireito. Aspectos Jurídicos e Metajurídicos. Rio de Janeiro: Forense, 2004.

MAFFI, Bruno. Reclamando, jun. 2010. Disponível em: <http://www.reclamando.com.br/ ?system=news\&action=read\&id=20370\&eid=319http://www.materbaby.com.br/clinica/ premios>. Acesso em: 22 abr. 2016.

OLIVEIRA, Fátima. Bioética uma face da cidadania. São Paulo: Ed. Moderna, 2004.

OLIVEIRA, Fátima. Engenharia genética: o sétimo dia da criação. São Paulo: Moderna, 1997.

OLIVEIRA, Simone Born de. Da bioética ao direito: manipulação genética e dignidade humana. Curitiba: Juruá, 2006. 
SANTOS, Maria Celeste Cordeiro Leite. Biodireito: ciência da vida, os novos desafios. São Paulo: Revista dos Tribunais, 2001.

SARLET, Ingo Wolfgang. As dimensões da dignidade da pessoa humana: construindo uma compreensão jurídico-constitucional necessária e possível. Revista Brasileira de Direito Constitucional - RBDC, n. 09, 2007.

SEQUEIROS, Inês Trinta; BENTO, Raquel Inês Martins. Estatuto do embrião: o início da vida. Revista Percursos, n. 28, jul./set. 2013. Disponível em: <https://comum.rcaap. pt/bitstream/10400.26/9264/1/Revista\%20Percursos\%20n28_Estatuto\%20do\%20 Embrião\%20-\%200\%20Início\%20de\%20Vida.pdf>. Acesso em: 17 set. 2016.

SILVA, Reinaldo Pereira da. Introdução ao biodireito: investigações político-jurídicas sobre o estatuto da concepção humana. São Paulo: LTr, 2002.

SOUZA, Paulo Vinicius Sporleder de. A criminalidade genética. São Paulo: Revista dos Tribunais, 2001.

SZANIAWSKI, Elimar. Direitos de personalidade e sua tutela. 2. ed. rev. atual e ampl. São Paulo: Revista dos Tribunais, 2005.

UNIVERSIA BRASIL. Primeira professora com Síndrome de Down recebe prêmio de educação. Disponível em: <http://noticias.universia.com.br/destaque/noticia/2015/10/30/1133136/ primeira-professora-sindrome-down-recebe-premio-educacao.html>. Acesso em: 22 abr. 2016.

VARGA, Andrew C. Problemas de bioética. São Leopoldo/RS: UNISINOS - Universidade do Vale do Rio dos Sinos, 1998.

WOLFF, Philip; MARTINHAGO, Ciro Dresch; UENO, Joji. Diagnostico genético pré-implantacional: uma ferramenta importante para a rotina de fertilização in vitro? FEMMA - Federação Brasileira Ginecologia e Obstetrícia, v. 37, 2009. Disponivel em: <http://www.febrasgo.org.br/site/ wp-content/uploads/2013/05/Femina-v37n6-297.pdf>. Acesso em: 02 jan. 2015.

Informação bibliográfica deste texto, conforme a NBR 6023:2002 da Associação Brasileira de Normas Técnicas (ABNT):

LOPES, Daniele Fernanda Gomes; RODRIGUES, Mithiele Tatiana. Diagnóstico genético de pré-implantação: reflexão à luz da discriminação genética. Direitos Fundamentais \& Justiça, Belo Horizonte, ano 10, n. 35, p. 127-147, jul./dez. 2016. 